\title{
Resistensi Warga di Bantaran Ciliwung terhadap Rencana Penggusuran oleh Pemerintah
}

\section{Citizens Resistance in Ciliwung River Against Plans for Eviction by the Government}

\author{
Pramudita, Budhi Gunawan \& Selly Riawanty*
}

Magister Antropologi, FISIP, Universitas Padjajaran, Indonesia

Diterima: 21 Desember 2019 ; Disetujui: 12 Mei 2020 ; Dipublish: 31 Desember 2020

\begin{abstract}
Abstrak
Tulisan ini penulis fokuskan terhadap topik mengenai normalisasi yang ternyata tidak selalu dapat diterima oleh masyarakat, hal tersebut menimbulkan resistensi pada masyarakat. Dalam penulisan ini, penulis menganalisis pola resistensi yang dijalankan oleh masyarakat di wilayah Tanah Rendah terhadap rencana penggusuran oleh pemerintah. Metode yang digunakan dalam penulisan ini adalah wawancara mendalam. Penulisan ini bersifat deskriptif-kualitatif. Hasil dari penulisan ini menunjukkan bahwa perlawanan oleh warga di kawasan tersebut bersifat tertutup dan dikategorikan sebagai resistensi tertutup. Dalam hidden transcript tampaknya warga mematuhi pemerintah dengan melaporkan luas tanah dan bangunannya dan menyatakan sepakat atas luas tanah dan bangunan yang telah diukur oleh petugas dari Badan Pertanahan Nasional, tetapi dalam public transcriptnya warga secara sembunyi-sembunyi tetap memperlihatkan ketidaksetujuan terhadap program normalisasi dari pemerintah.

Kata Kunci: Resistensi, Masyarakat, Kebijakan.
\end{abstract}

\section{Abstract}

This paper focuses on the topic of normalization which apparently is not always acceptable to the community, it raises resistance to the community. In this study entitled "Citizens Resistance in Ciliwung River Against Plans for Eviction by the Government ", the researcher looked at how the resistance patterns carried out by the people in the Low Land area. The method used in this research is in-depth interviews. This research is descriptive-qualitative in nature. The results of this study indicate that resistance by residents in the region is closed and categorized as closed resistance. In hidden transcripts it appears that citizens obey the government by reporting the area of land and buildings and agreeing on the area of land and buildings that have been measured by officials from the National Land Agency, but in public transcripts the citizens clandestinely continue to show disapproval of the normalization program from the government Keywords: Resistance, Citizen, Policy

How to Cite: Pramudita, Gunawan, B., \& Rianwaty, S. (2020). Resistensi Warga di Bantaran Ciliwung Terhadap Rencana Penggusuran Oleh Pemerintah, JUPIIS: Jurnal Pendidikan Ilmu-ilmu Sosial, 12 (2): 288-296.

*Corresponding author:

E-mail: aditsolkey @gmail.com
ISSN 2549-1660 (Print)

ISSN 2550-1305 (Online) 


\section{PENDAHULUAN}

Isu resistensi semakin mengemuka akhir-akhir ini mengingat semakin banyaknya warga yang bermukim di kawasan bantaran sungai, yang jelas-jelas melanggar peraturan pemerintah yang tertuang dalam Peraturan Pemerintah No.35 Tahun 1991 tentang sungai.

Menurut Foucault (1977), di mana ada afirmasi kekuasaan, di situ ada resistensi. Isu mengenai resistensi memang saling berhubungan dengan kebijakan yang ada, Hal tersebut dapat kita analogikan dengan banyaknya kepentingan warga terhadap tempat tinggal yang layak di bantaran Sungai Ciliwung yang senantiasa tersandung dengan kebijakan pemerintah tentang normalisasi Sungai Ciliwung. Pemukiman di bantaran Sungai Ciliwung di Jakarta semakin padat dan dianggap pemerintah mengancam kelestarian dan kualitas air sungai serta meningkatnya sumber pencemaran limbah domestik.

Paradigma konflik berbasis kultural menyiratkan bahwa memahami konflik yang tengah berlangsung perlu dipahami melalui perspektif masyarakat yang bersangkutan, perspektif ini menghasilkan konsep mengenai resistensi, tetapi resistensi tersebut sebenarnya tidaklah mudah diamati, terkadang kita menganggap suatu kelompok masyarakat adalah sepihak padahal di konteks yang lain mereka bisa saja menjadi lawan (Fedyani, 2015 ).

Sepanjang sejarah dalam dua abad terakhir ini hubungan itu kian bergeser ke model yang demokratik, dengan keyakinan bahwa bukan kekuasaan negara itu yang bersifat kodrati, melainkan hak hak manusia individual warga negara itulah yang asasi. Adalah merupakan proposisi paradigma model demokratik ini bahwasanya seluruh kekuasaan para pejabat negara itu adalah hanyalah derivat dari hak-hak asasi manusia warganya, yang oleh sebab itu harus diterima sebagai sesuatu yang limitatif sifatnya “(Wignjosoebroto, 1995 ).

Mengingat masyarakat adalah sejumlah manusia yang merupakan satu kesatuan golongan yang berhubungan tetap dan mempunyai kepentingan yang sama, seperti : sekolah, keluarga, perkumpulan, negara, kehidupan masyarakat tentunya juga terkait dengan politik dan sebaliknya. Dalam hal ini politik bukan saja satu sistem kecil dalam sistem sosial besar, tetapi juga mengandung satu koleksi nilai yang bukan politik untuk membolehkan kita menguraikan aspekaspek ini, yang ada hubungannya dengan politik, perlulah kita mengkaji masyarakat secara keseluruhannya ( Sianipar, 2002 )

Orang kota pada umumnya dapat mengurus dirinya sendiri tanpa harus bergantung pada orang lain. Yang terpenting di sini adalah manusia perorangan atau individu. Di kota-kota kehidupan keluarga sering sukar untuk disatukan, sebab perbedaan kepentingan, paham politik, perbedaan agama dan sebagainya (Nurdinah, 2017)

Penelitian terdahulu oleh Andri (2011), menunjukkan bahwa ancaman penggusuran yang akan dilakukan Pemerintah Propinsi dan Kota kepada warga masyarakat bantaran sungai/stren kali hingga sekarang masih belum bisa terselesaikan oleh pihak-pihak terkait, bahkan meninggalkan trauma mendalam, ketidakpastian tempat tinggal, kehilangan lapangan pekerjaan, dan terhentinya pendidikan anak-anak, jika penggusuran dilakukan. 
Dominasi dan eksploitasi kaum borjuis terhadap kaum proletar mendorong adanya usaha resistensi untuk mengubah nasib dari kaum proletar. Sejak saat ini perjuangan antara yang proletar dan yang borjuis menjadi suatu struktur identitas tersendiri dalam masyarakat. Strategi resistensi pada masa ini cenderung bersifat revolusioner dengan menggunakan jalan kekerasan. Menariknya, meskipun struktur dasar resistensi pada awalnya bersifat ekonomi, namun membawa serta unsur perubahan politik di dalamnya. Hal ini terjadi karena interseksi keduanya tidak bisa dipisahkan sehingga dibutuhkan resistensi secara holistic (Wiyatmoko, 2011 )

Menurut Maring dalam (Fikri, 2017), bahwa praktik kekuasaan yang ditunjukkan aparat pemerintah terhadap penguasaan wilayah tertentu seperti misalnya hutan Noge di Tanaloran, Flores, memicu perlawanan dari masyarakat lokal untuk mendapatkan distribusi sumber daya secara adil dan kepastian hak milik. Perlawanan dari masyarakat dilakukan secara terbuka, antara lain dengan menduduki areal lahan, melakukan penyekapan, demonstrasi bahkan perkelahian fisik. Semua dilakukan untuk mematahkan dominasi kekuasaan pemerintah atas hutan demi untuk mendapatkan distribusi sumber daya hutan secara adil dan mendapatkan kepastian hak milik.

Penelitian tentang resistensi warga Katobengke di Buton, menyatakan bahwa kelompok Kaomuwalaka sebagai kelompok yang dominan membedakan diri mereka dari kelompok Papara. Ada beberapa simbol yang membedakan ketiga lapisan sosial (kaomu, walaka dan papara) berkenaan dengan kekuasaan, privilege dan prestise yang dimiliki oleh kelompokkelompok tersebut dalam berinteraksi pada masa kesultanan (Tasrifin, 2012)

Dari beberapa hasil penelitian di atas, maka, dalam artikel ini, penulis menganalisis pola resistensi yang dijalankan oleh masyarakat di wilayah Tanah Rendah terhadap wacana normalisasi di kawasan bantaran sungai Ciliwung, dengan cara memperhatikan sikap dan respon warga terhadap rencana normalisasi Sungai Ciliwung tersebut.

\section{METODE PENULISAN}

Penulisan ini adalah penulisan yang bersifat deskriptif-kualitatif mengenai sistem-sistem tersebut berupa sikap resistensi masyarakat yang berhadapan dengan kebijakan pemerintah mengenai normalisasi Sungai Ciliwung. Kesesuaian pemikiran Foucault (Mudhofir, 2013) dalam konteks resistensi terhadap kebijakan normalisasi di bantaran Sungai Ciliwung adalah bagaimana pemerintah Provinsi DKI Jakarta dengan kekuasaan yang dijalankannya melarang warganya tinggal di bantaran Sungai Ciliwung tersebut justru melahirkan resistensi. Semakin kuat kekuasaan itu menciptakan hegemoni untuk berkuasa, maka dengan sendirinya semakin besar peluang untuk terjadinya resistensi.

Bentuk penulisan ini adalah bersifat deskriptif kualitatif karena emosi atau rasa sentimen penduduk di bantaran kali Ciliwung tersebut tidak dapat terukur dengan kuantitas, karena metode deskriptif kualitatif ini akan bersifat observasi partisipatoris.

Dalam hal ini perlawanan masyarakat berhadapan dengan kebijakan, yakni kebijakan mengenai normalisasi Sungai Ciliwung. Penulis melihat pola resistensi 
dengan cara melakukan observasi terhadap sikap masyarakat terhadap kebijakan serta melihat tindakan masyarakat yang dapat menggambarkan resistensi tersebut, baik dalam bentuk gerakan perlawanan, gerakan dalam bentuk organisasi non pemerintah ataupun dengan mengajukan advokasi terkait lahan tempat tinggal mereka. Sehingga dengan melakukan observasi mendalam yang bersifat observasi partisipatoris penulis akan menggali fakta-fakta serta fenomena yang tidak selalu eksplisit dan tampak nyata di kehidupan sosial.

Maka yang menjadi fokus penulis dalam tulisan ini adalah: Pola Resistensi Masyarakat di bantaran Sungai Ciliwung di Kelurahan Kampung Melayu terhadap wacana kebijakan.

Adapun untuk melihat pola resistensi tersebut dengan indikator sebagai berikut: Perlawanan secara fisik (tetap tinggal di lokasi penulisan dan melawan petugas ketika rumahnya diukur petugas, mendirikan bangunan tambahan di pinggir sungai, menebang pohon yang ada di pinggir sungai). Perlawanan secara non fisik (membandel dengan cara mengabaikan himbauan pemerintah untuk tidak tinggal di kawasan yang merupakan zona merah, mengajukan advokasi terhadap status tanahnya, bekerja sama dengan pihak luar untuk mempertahankan status tanahnya)

\section{HASIL DAN PEMBAHASAN Normalisasi Sungai Ciliwung}

Normalisasi Sungai Ciliwung yang merupakan proses pembuatan dinding turap beton atau sheetpile pada sisi Sungai Ciliwung sedalam 10 hingga 12 meter ke bawah sungai. Biaya proyek ini terbagi atas beberapa bagian, diantaranya Rp 2 triliun pada tahun 2013, Rp 500 Miliar untuk konstruksi sodetan, Rp 300 Miliar untuk penyediaan pompa dan MCK, dan Rp.1,18 triliun pada November 2013. Proyek ini diprakarsai oleh Kementerian Pekerjaan Umum dan Perumahan Rakyat, Balai Besar Wilayah Sungai Ciliwung Cisadane (BBWSCC) pada Desember 2012 yang berkerja sama dengan Pemerintah Provinsi DKI Jakarta yang bertugas mengadakan pembebasan lahan. Proyek Normalisasi Sungai Ciliwung terbentang dari kawasan Jembatan Jl. T.B Simatupang hingga Pintu Air Manggarai, Jakarta Selatan. Kendala utama proses normalisasi Ciliwung adalah pembebasan lahan, yang disebabkan tiga hal, yakni administrasi, relokasi, dan gugatan hukum yang dilakukan masyarakat (https://id.wikipedia.org/wiki/Normalisas i_Sungai_Ciliwung)

Dari normalisasi inilah, kemudian warga Kelurahan Kampung Melayu melakukan penolakan atau resistensi terhadap upaya tersebut. Pola resistensi warga menunjukkan bahwa mereka bersikap seolah-olah mematuhi pemerintah dengan melaporkan luas tanah dan bangunannya dan menyatakan sepakat atas luas tanah dan bangunan yang telah diukur oleh petugas dari Badan Pertanahan Nasional, tetapi secara sembunyi-sembunyi warga tetap memperlihatkan ketidaksetujuan terhadap program normalisasi dari pemerintah.

Berdasarkan Peraturan Pemerintah Republik Indonesia Nomor 38 Tahun 2011 Tentang Sungai, pada Pasal 22 (1) Perlindungan sempadan sungai sebagaimana dimaksud dalam Pasal 20 ayat (2) huruf b dilakukan melalui pembatasan pemanfaatan sempadan sungai. (2) Dalam hal di dalam sempadan sungai terdapat pembatas untuk kepentingan pengendalian 
banjir, perlindungan badan tanggul dilakukan dengan larangan: a) Menanam tanaman selain rumput; b) Mendirikan bangunan; dan c) Mengurangi dimensi tanggul

(http://ditjenpp.kemenkumham.go.id/arsi p/ln/2011/pp38-2011.pdf).

Dalam hal ini pemerintah membuat kategori untuk wilayah yang dilarang mendirikan bangunan, yaitu adalah di area sempadan sungai, namun realita yang terjadi di lokasi penelitian bertolak belakang dengan peraturan yang dibuat oleh pemerintah. Beberapa warga masih mendirikan bangunan di zona yang dilarang mendirikan bangunan, terkait dengan Sungai Ciliwung yang memiliki kedalaman kurang dari 3 meter maka batasan area sempadan sungai nya adalah paling sedikit 10 meter dari bantaran atau tepi air.

Kondisi air di Sungai Ciliwung kian memburuk, bahwa pencemaran limbah domestik akibat tingginya kandungan amonia, fosfat, deterjen dan bakteri coli. Beban limbah domestik yang masuk ke Sungai Ciliwung sudah terlihat cukup tinggi di awal masuk wilayah Jakarta, hal ini mengindikasikan bahwa pencemaran terjadi tidak hanya di wilayah Jakarta tetapi juga di wilayah Depok atau Bogor. (Satmoko, 2018)

Fenomena ini dapat berimplikasi baik secara sosial, ekonomi dan politik. Pelanggaran hukum yang dilakukan oleh warga sudah semakin masif yang berakibat terjadinya kawasan yang rawan banjir. Perilaku manusia yang tidak bijaksana dalam pemanfaatan ruang dan pengelolaan ini juga memicu terjadinya bencana banjir dan longsor, padahal sesungguhnya para leluhur orang Sunda pada masa silam mempunyai kearifan ekologi dalam pemanfaatan tata ruang dan perilaku bijaksana terhadap lingkungannya ( Iskandar, 2016 )

Dalam pengamatan yang dilakukan oleh peneliti, banyak ditemukan bangunan yang menjorok ke bantaran sungai sehingga wilayah bantaran sungai banyak yang dimanfaatkan oleh warga untuk sebagai tempat mencuci piring, pakaian hingga alat rumah tangga lainnya selain hal tersebut banyak di antara warga yang tinggal di bantaran sungai meletakkan barang rongsokan di pinggiran sungai yang mereka anggap seperti pekarangan rumahnya.

Walaupun banyak warga yang kurang setuju dalam Peraturan pemerintah No. 38 Tahun 2011 tentang sungai, namun Pemerintah provinsi DKI Jakarta yang dalam hal ini adalah Pemerintah Kelurahan Kampung Melayu tetap mempersiapkan persiapan awal jika suatu saat Gubernur Provinsi DKI Jakarta mengeluarkan kebijakan untuk merelokasi penduduk di wilayah Tanah Rendah untuk kepentingan program normalisasi Sungai Ciliwung.

Dalam mempersiapkan program normalisasi yang prosesnya secara teknis belum ditentukan waktunya hingga Bulan Agustus 2019, saat ini pihak Kelurahan Kampung Melayu dan Badan Pertanahan Nasional (BPN) bekerja sama dalam masalah pengukuran tanah dan bangunan warga yang tempat tinggalnya berada di bantaran sungai sehingga hasil pengukuran tersebut dicatat oleh petugas dari BPN sebagai pedoman membuat daftar inventarisasi tanah dan bangunan yang nantinya akan dieksekusi dalam waktu yang belum dapat ditentukan oleh pihak Pemerintah Provinsi DKI Jakarta, setelah itu pihak pemerintah di Kelurahan Kampung Melayu mengadakan sosialisasi 
rencana program normalisasi melalui Lembaga Masyarakat Kota (LMK) yang diutus pihak Kelurahan Kampung Melayu untuk mensosialisasikan program kerja dari tingkat kelurahan ke tingkat RW yang berada di bawah Kelurahan Kampung Melayu melalui surat dan kadangkala melalui pertemuan langsung di pos RW yang berada di Kantor Kelurahan Kampung Melayu.

Upaya pemerintah dalam menangani banjir ini lebih banyak terfokus pada sistem infrastruktur sungai, mulai pelebaran sungai, pengerukan sungai, membuat codetan sungai, hingga membuat kanal tambahan untuk menyalurkan limpahan air yang berlebih di sungai-sungai utama di Jakarta.

Solusi yang dilakukan pemerintah DKI Jakarta sering menimbulkan masalah baru dan menuai berbagai protes, bukan hanya karena kebijakan Pemerintah kurang melibatkan warga dalam pengambilan keputusan, tetapi juga karena penekanannya pada ketertiban dan keamanan berujung pada penggusuran.

Hal tersebutlah yang menimbulkan resistensi pada pembangunan di Jakarta. Ketidaksinergian antara Pemerintah dengan masyarakat serta berbedanya kepentingan antara Pemerintah dengan masyarakat tidak kunjung menemukan titik temunya.

Meskipun terdapat respon negatif terhadap wacana normalisasi Sungai Ciliwung oleh warga yang bermukim di bantaran sungai di wilayah Tanah Rendah, namun Pemerintah Provinsi DKI Jakarta yang dalam hal ini adalah Kelurahan Kampung Melayu tetap menghimbau warga untuk meninggalkan tempat tinggalnya, khususnya bagi rumah atau bangunan yang menempati tanah negara dan melakukan langkah awal sebelum turunnya kebijakan yang lebih lanjut dari gubernur DKI Jakarta, berupa persiapan awal seperti inventarisasi dan pendataan awal untuk pembebasan lahan di wilayah pemukiman yang ada di bantaran sungai, termasuk dalam hal ini adalah antisipasi banjir kiriman dari wilayah hulu (Kabupaten Bogor) dengan cara mendirikan posko siaga banjir sementara untuk mencegah kemungkinan-kemungkinan buruk yang timbul karena terjadinya banjir yang melanda pemukiman padat di Tanah Rendah.

\section{Keterikatan Penduduk Dengan Tempat Tinggalnya}

Akibat dari urbanisasi yang pesat tersebut, dengan keterbatasan yang mereka miliki dalam mengakses tanah di tempat yang layak di Jakarta yang harganya semakin tinggi, menyebabkan pendatang memilih tempat di mana aja asal bisa hidup seperti di pinggir-pinggir rel kereta api atau di pinggiran bantaran sungai. Kampung Melayu yang punya potensi yang strategis dimana disatu sisi mereka menganggap bisa mencari nafkah dengan mudah dan tinggal secara murah di pinggiran bantaran Sungai Ciliwung yang kian hari semakin padat.

Dalam melihat keterikatan penduduk dengan tempat tinggalnya, penulis menggunakan model teknik analisa Miles dan Huberman. Berdasarkan hasil penulisan menunjukan setiap subjek memiliki rasa keterikatan terhadap wilayah bantaran Sungai Ciliwung di Kelurahan Kampung Melayu. Dimensi identitas lokal digambarkan dari identitas mereka sebagai warga asli atau warga yang lahir di kawasan Kelurahan Kampung Melayu. Perasaan kuatnya ikatan itu digambarkan 
oleh kenyamanan, perasaan senang, kerukunan yang ada pada masyarakat sekitar. Ketergantungan terhadap tempat tinggalnya digambarkan oleh ketergantungan masyarakat yang mayoritas berprofesi sebagai pedagang di Kelurahan Kampung Melayu terhadap Pasar Jatinegara sebagai lokasi pencaharian utama masyarakat sekitar, juga ketergantungan terhadap lahan terbuka yang harga sewa tanahnya relatif murah menurut warga yang berprofesi sebagai pembuat tempe.

Dalam tulisan ini penulis mewawancarai beberapa warga dan membaginya dalam dua kategori untuk kepentingan kategorisasi data. Kategori tersebut antara lain sebagai berikut :

Warga Asli, : yakni masyarakat yang sejak lahir sudah menempati tempat tinggalnya di kawasan 'tanah rendah' Kelurahan Kampung Melayu.

Warga Pendatang: Yakni merupakan warga yang tinggal di kawasan tersebut dan karena faktor tertentu seperti karena menikah, karena merantau ke lokasi tersebut dan sebagainya, intinya adalah warga pendatang ini lahir di luar lokasi tersebut, dan hanya tinggal di lokasi tersebut untuk alasan tertentu pula. Banyak dari warga pendatang ini telah bermukim di kawasan 'tanah rendah' dalam waktu yang cukup lama, seperti halnya salah satu warga yang bernama Bu Subaikah yang sudah tiga puluh tahun tinggal di kawasan tersebut. Oleh karena itu jika penulis menanyakan kepada para warga yang sudah puluhan tahun lamanya tinggal dikawasan tanah rendah ini maka mereka akan menjawab sebagai warga asli. Namun untuk kepentingan kategorisasi data, maka penulis tetap membuat perbedaan kategori antara warga asli dan warga pendatang.

\section{Resistensi Masyarakat di Kawasan Tanah Rendah}

Menurut Scott (1992) terdapat beberapa bentuk resistensi yaitu: 1) Resistensi tertutup (simbolis atau ideologis) yaitu gossip, fitnah, penolakan terhadap kategori-kategori yang dipaksakan kepada masyarakat, serta penarikan kembali rasa hormat kepada pihak penguasa. 2) Resistensi semi-terbuka (protes sosial atau demostrasi), 3) Resistensi terbuka, merupakan bentuk resistensi yang terorganisasi, sistematis dan berprinsip. Manifestasi yang digunakan dalam resistensi adalah cara-cara kekerasan (violent) seperti menampar, menimpuk, meludahi, melempar, membentak, memaki, menghina, meneriaki, mengucilkan, memelototi, mencibir, dan memandang penuh ancaman.

Resistensi merupakan salah satu faktor yang penting dalam kehidupan manusia, karena pada dasarnya resistensi adalah oposisi terhadap kekuasaan dan dilembagakan dengan cara tertentu (Ortner, 2006)

Hidden transcript merupakan bentuk perlawanan tersembunyi untuk menghindari tindakan represif dari kelas superordinat (Aisyah, 2018)

Di wilayah Tanah Rendah, bentuk resistensi yang ada hanyalah resistensi tertutup dan semi-terbuka. Hal ini mengingat tidak pernah terjadinya kontak fisik antara warga dengan aparat atau petugas yang akan mengeksekusi tempat tinggal mereka, hal tersebut dikarenakan tahapan dalam wacana normalisasi masih dalam tahapan inventarisasi awal, jadi 
belum sampai pada tahapan eksekusi bangunan.

Resistensi tertutup yang dapat penulis amati di lokasi penelitian adalah: 1) Ungkapan rasa kurang setuju oleh warga yang disepakati antara gosip ibu-ibu yang belanja di warung terhadap rencana normalisasi yang mereka ketahui dari kegiatan inventarisasi awal oleh pihak Pemerintah Provinsi DKI Jakarta. Hal ini penulis temukan pada saat melakukan wawancara dengan seorang ibu yang sedang belanja di warung yang kebetulan sedang ramai ibu rumah tangga lainnya yang sedang berbelanja di warung yang menjual kebutuhan dapur seperti sayuran dan bumbu masakan. Pada saat penulis menanyakan perihal normalisasi sungai, para ibu rumah tangga yang sedang berbelanja di warung tersebut menjawab dengan kompak jika mereka kurang setuju dengan rencana normalisasi jika hal tersebut menyebabkan mereka pindah dari tempat tinggalnya yang berada di kawasan bantaran sungai; 2) Ungkapan rasa kurang setuju oleh individu terhadap normalisasi yang berdampak pada relokasi penduduk ke rusunawa. Pada saat penulis mewawancarai beberapa warga yang tinggal di bantaran sungai sehingga tempat tinggalnya termasuk kedalam daftar inventarisasi oleh Pemerintah Provinsi DKI Jakarta; 3) Ungkapan yang menyudutkan suatu institusi atau pihak tertentu; 4) Pelanggaran hukum oleh masyarakat terhadap batas wilayah yang diizinkan untuk mendirikan bangunan.

\section{SIMPULAN}

Jika dikaitkan dengan teori Scott mengenai hidden transcript dan Public transcript, maka peneliti dapat menarik kesimpulan bahwa dalam hidden transcript tampaknya warga di kawasan Tanah Rendah Kampung Melayu mematuhi pemerintah dengan melaporkan luas tanah dan bangunannya dan menyatakan sepakat atas luas tanah dan bangunan yang telah diukur oleh petugas dari Badan Pertanahan Nasional, tetapi dalam public transcript nya warga secara sembunyisembunyi tetap memperlihatkan ketidaksetujuan terhadap program normalisasi dari pemerintah.

\section{DAFTAR PUSTAKA}

Aisyah, S. M. ( 2018) Praktek Dominasi Kuasa Dalam Paguyuban Duta Wisata Diunduh di http://repository.unair.ac.id/75092/4/JURN AL_Fis.S.44\%2018\%20Ais\%20pdf ,pada tanggal 12 Desember

Andri, A. (2011). "Festival Jogokali" : Resistensi Terhadap Penggusuran dan Gerakan SosialKebudayaan Masyarakat Urban. Jurnal Sosiologi Islam. Vol 1 (2):85-94

Fedyani, A. (2015). Logika Antropologi : Suatu Percakapan Mengenai Dasar Paradigma. Jakarta : Prenadamedia Group.

Fikri, M (2017). Relasi Kuasa Dalam Perebutan Lahan di Situs Candi Bojongmenje. Jurnal Umbara Vol 2: 45-55

Foucault, M. (1977). Discipline and Punish:The Birth of The Prison, NewYork : Pantheon Books.

Iskandar, J. (2016). Etnobiologi dan Keragaman Budaya di Indonesia. Jurnal Umbara VOL 1: 27-42

Mudhofir, M. (2013). "Teori Kekuasaan Michel Foucault: Tantangan bagi Sosiologi Politik". Jurnal Sosiologi MASYARAKAT Vol. 18: 75100

Nurdinah, M. (2017). Resistensi Masyarakat Urban Dan Masyarakat Tradisional Dalam Menyikapi Perubahan Sosial. Jurnal Substantia, Volume 19 Nomor 2. 149-168

Ortner, S.B. (2006). Resistance and the Problem of Ethnographic Refusal, Anthropology and Social Theory : Culture, Power,And The Acting Subject. Durham. Duke University Press

Satmoko, Y. (2018). Status Kualitas Air Sungai Ciliwung di Wilayah DKI Jakarta. Jurnal Teknologi Lingkungan Vol 19: 13-22

Scott, J.C. (1992). Domination and the Arts of Resistence. , Yale University Press

Sianipar, T. (2002). Antropologi Politik: Pengkajian Pendekatan Tingkah Laku dan Kebudayaan Menyoroti Pergerakan Aktor Politik. Jurnal 
Pramudita, Budhi Gunawan dan Selly Riawanti, Resistensi Warga di Bantaran Ciliwung Terhadap

Sosiohumaniora, Vol. 4 No. 1, Maret 2002: 15 $-25$

Tasrifin. (2012). Reproduksi Stereotip dan Resistensi Orang Katobengke Dalam Struktur Masyarakat Buton. Jurnal Antropologi Indonesia Vol 33: 75-97

Wignjosoebroto, S. (1995). Dari hukum kolonial ke hukum nasional: dinamika sosial-politik dalam perkembangan hukum di indonesia
Widyatmoko, A. (2011). Identitas dan Prospek Resistensi Dalam Globalisasi. Jurnal Global \& Strategis, Edisi Khusus : 271-287

Sumber dari internet :

(http://ditjenpp.kemenkumham.go.id/arsip/ln/20 11/pp38-2011.pdf). Diakses tanggal 25 Desember 2019

https://id.wikipedia.org/wiki/Normalisasi_Sungai_ Ciliwung Diakses tanggal 25 Desember 2019. 